\title{
Transformative Diversity Changes in U.S. Demographics: Recognizing the Cultural Implications in Higher Education
}

\section{Dr. Mitchell L. Springer PMP, SPHR, SHRM-SCP, Purdue University, West Lafayette}

\section{Dr. Mitchell L. Springer PMP, SPHR, SHRM-SCP}

Dr. Springer currently serves as an Executive Director for Purdue University's Polytechnic Institute located in West Lafayette, Indiana. He has over thirty-five years of theoretical and defense industry-based practical experience from four disciplines: software engineering, systems engineering, program management and human resources. Dr. Springer possesses a significant strength in pattern recognition, analyzing and improving organizational systems. He is internationally recognized and has contributed to scholarship more than 300 books, articles, presentations, editorials and reviews on software development methodologies, management, organizational change, and program management. Dr. Springer sits on many university and community boards and advisory committees. He is the recipient of numerous awards and recognitions, including local, regional and national recognitions for leadership in diversity, equity and inclusion; as well as, recognition for exceptional teaching and support of military connected students.

Dr. Springer is the President of the Indiana Council for Continuing Education as well as the Past-Chair of the Continuing Professional Development Division of the American Society for Engineering Education.

Dr. Springer received his Bachelor of Science in Computer Science from Purdue University, his MBA and Doctorate in Adult and Community Education with a Cognate in Executive Development from Ball State University. He is certified as a Project Management Professional (PMP), Senior Professional in Human Resources (SPHR \& SHRM-SCP), in Alternate Dispute Resolution (ADR), and, in civil and domestic mediation. Dr. Springer is a State of Indiana Registered domestic mediator.

\section{Dr. Kathryne A. Newton, Purdue Polytechnic Institute}

Dr. Kathy Newton is an Associate Dean of Graduate Programs and Faculty Success for the Purdue Polytechnic Institute at Purdue University. She is a Professor of Supply Chain Management Technology in the School of Engineering Technology. Her teaching and scholarly interests are in the areas of supply chain management, quality control, and graduate education. She served as Department Head of Industrial Technology from 2007 to 2010. Prior to her appointment at Purdue University in 1993, she spent seven years teaching for Texas A\&M University's Department of Engineering Technology. Dr. Newton has a Ph.D. in Educational Human Resource Development, a Master's degree in Business Administration, and a B.S. in Industrial Distribution, each from Texas A\&M University. 


\title{
Transformative Diversity Changes in U.S. Demographics: Recognizing the Cultural Implications in Higher Education
}

\begin{abstract}
The demographic face of the United States is changing in a way never before seen. The year 2035 will see the culmination of three major forces: (1) the last of the Baby Boomers turning 65+ years of age (2030), (2) the cross-over where the number of people 65+ years of age outnumber the youths under the age of 18 (2035), and, (3) the recognition that the primary driver for population growth in the U.S. will be from international migration (2030).

These three major events will take place over the upcoming decade. Each of which, by itself, may appear relatively harmless and unnoticed. Together these three transformative changes paint a forever changing face of the demographics of the U.S. The impact of these three primary drivers of demographic change are already being felt in the faces and diversity ratios in higher education. Colleges and universities are scrambling to accommodate these, still to be fully understood, tectonic shifts.

The new demographic of the United States has had a negative impact on enrollments in higher education. New minority populations are not generally equally prepared, financially or from a family support perspective, to participate in higher education as the current non-Hispanic White majority population. To this end, 25 years of researched literature materializes into multiple changes currently being implemented by institutions of higher education to accommodate this new minority majority population.

This paper, while addressing the changing nature of higher education, deals explicitly with the greater cultural implications of these many demographic changes and their impact on higher education. Universities faculties and administrators will, for a while, be faced with a majority of students that do not look like them and will have to learn to adjust accordingly. This paper addresses the basic subconscious and unconscious qualitative behavioral characteristics at the root of major decisions. It looks at the decision process itself and how the process errors on the side of an often times referred to term in higher education - "collegiality". This paper lays a foundation for making better, more informed decisions on inclusivity in higher education.

In the final analysis, this paper is the assimilation of a rich, systematic literature review which recognizes the many potential, highly charged and emotional implications of changing demographics. It concludes with potential solutions for culturally adjusting to this new American demographic reality.
\end{abstract}




\section{Introduction - Changing U.S. Demographics}

The U.S. population, on the whole, is expected to grow more slowly, age considerably and become significantly more racially and ethnically diverse.

It is expected the U.S. population will reach roughly 400 million people in the year 2058 [1, p. 2]. At this writing, according to the U.S. Census Bureau's World Population Clock, the U.S. population is 329 million; with one birth every eight seconds, one death every twelve seconds, one international migrant every twenty-eight seconds, for a net gain of one person every twelve seconds. The U.S. population is increasing, at a decreasing rate. Through the year 2030, the population grew at a rate of 2.3 million people per year. However, going forward from 2030, the population is expected to grow at a much slower rate of 1.5 million people per year from 2040 to 2060. The decrease in the rate of growth is predominantly due to an ageing Boomer population and declining fertility rates of the U.S. majority non-Hispanic White female population.

The figure below [1, p. 9] depicts the calculation of population between 2017 and 2060. It takes into account the births by demographic cohorts, native-born mothers versus foreign-born mothers living in the U.S. Accounting for births by individual native-born, foreign-born, racial and ethnic cohorts is critical given the differences in fertility rates between these populations. Deaths is figured the same way as births; again, accounting for differences between native-born, foreignborn, racial and ethnic cohorts. Net immigration, discussed later, becomes an increasingly greater percentage of the population; not because of an increase in immigration, but because of an ageing majority non-Hispanic White population coupled with a declining birth rate of same.

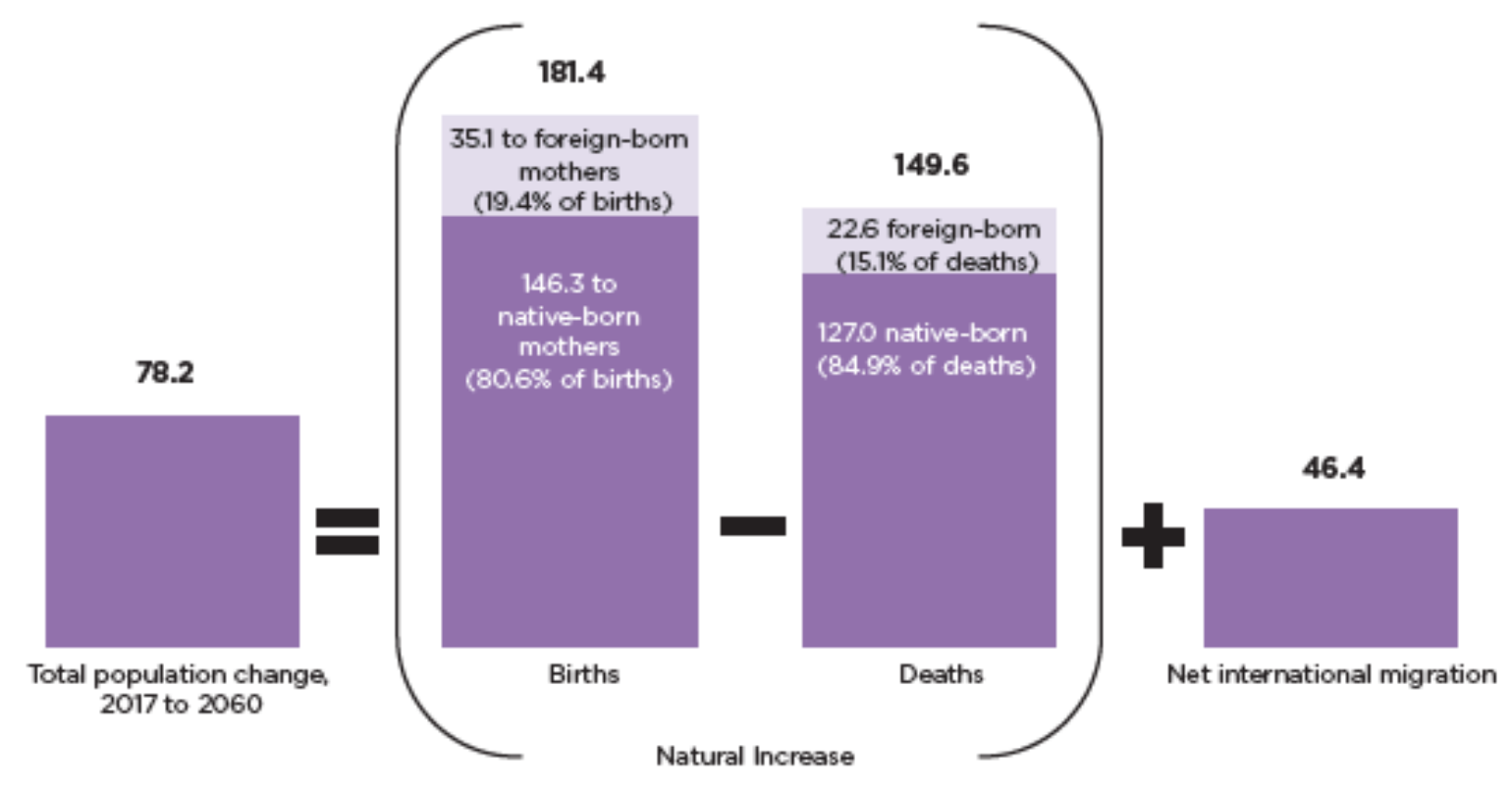

Source: U.S. Census Bureau, 2077 National Population Projections.

Figure 1 - Population Change 2017 - 2060 
The Baby Boomers were born between 1946 and 1964. The last of the youngest Boomers, those born in 1964, will turn 65 years of age in the year 2029; marking 2030 as the first year all boomers will be at least 65 years old. This single fact has enormous implications, sociologically, economically and without any doubt demographically. This change is coming and is inevitable.

Figure 2 below [1, p.1] depicts the changing age demographic of those 65 years of age and older by calendar year. As can be seen the U.S. has a generally ageing population with greater percentages of total population being 65 years of age and older as time progresses. By 2020, 17\% of the total U.S. population will be 65 years of age and older, by 2030, 21\% of the U.S. population will be 65 years of age and older, and by 2060, nearly one quarter of the entire U.S. population will be over the age of 65 .

Millions of people 65 and older

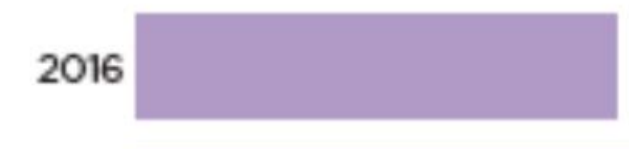

$2 \mathrm{O} 2 \mathrm{O}$

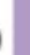

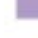

49.2

56.1
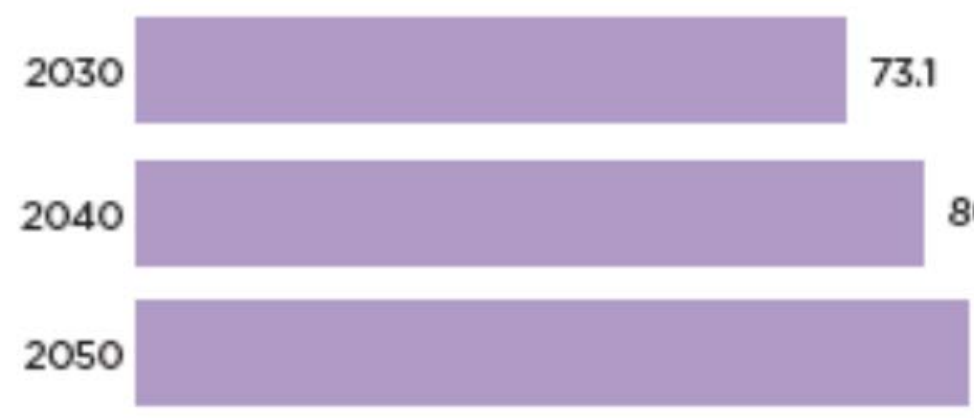

2060
73.1

80.8

85.7

94.7
15

17

21

22

22

23

Source: US. Census Bureau, 20T7 National Population Projections.

Figure 2 - Percentage of Population 65 Years of Age and Older

In the U.S., the working age population is considered to be between the ages of 18 and 64 . Those below the age of 18 are calculated as the youth population, while those age 65 and above are considered the senior, or aged, non-working population. In the ideal scenario, the backfill of an aged population is the youth population. This younger population becomes the working age 
population of a society and ensures the continuation of social programs such as social security, Medicare and Medicaid for the aged population. The year 2035 marks the first time in U.S. history the older $\left(65^{+}\right)$population is expected to outnumber the youth (under 18) population [2, p. 3]. Figure 3 below depicts the actual expected number of individuals in each of these age categories. From figure 3, it can be seen in the year 2030, the under 18 population is at 18.4 million, while the 65 and above population is at 73.1 million. By 2040, however, the under age 18 population is at 76.8 million, while the over 65 age population is at 80.8 million. The actual cross-over in population projections occurs in 2035.

\begin{tabular}{|c|c|c|c|c|c|c|c|c|}
\hline \multirow[t]{2}{*}{ Characteristic } & \multicolumn{6}{|c|}{ Population } & \multicolumn{2}{|c|}{$\begin{array}{l}\text { Change from } \\
2016 \text { to } 2060\end{array}$} \\
\hline & 2016 & 2020 & 2030 & 2040 & 2050 & 2060 & Number & Percent \\
\hline Total population ..... . & 323.1 & 332.6 & 354.8 & 373.1 & 388.3 & 403.7 & 80.6 & 24.9 \\
\hline 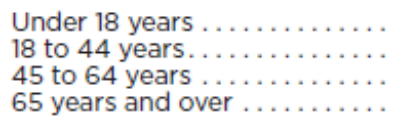 & $\begin{array}{r}73.6 \\
116.0 \\
84.3 \\
49.2\end{array}$ & $\begin{array}{r}73.9 \\
119.2 \\
83.4 \\
56.1\end{array}$ & $\begin{array}{r}75.4 \\
125.0 \\
81.3 \\
73.1\end{array}$ & $\begin{array}{r}76.8 \\
126.3 \\
89.1 \\
80.8\end{array}$ & $\begin{array}{r}77.9 \\
129.3 \\
95.4 \\
85.7\end{array}$ & $\begin{array}{r}79.8 \\
132.3 \\
97.0 \\
94.7\end{array}$ & $\begin{array}{r}6.2 \\
16.3 \\
12.8 \\
45.5\end{array}$ & $\begin{array}{r}8.4 \\
14.1 \\
15.1 \\
92.3\end{array}$ \\
\hline $\begin{array}{l}85 \text { years and over } \ldots \ldots \ldots \ldots \\
100 \text { years and over } \ldots \ldots \ldots \ldots\end{array}$ & $\begin{array}{r}6.4 \\
0.1\end{array}$ & $\begin{array}{r}6.7 \\
0.1\end{array}$ & $\begin{array}{l}9.1 \\
0.1\end{array}$ & $\begin{array}{r}14.4 \\
0.2\end{array}$ & $\begin{array}{r}18.6 \\
0.4 \\
\end{array}$ & $\begin{array}{r}19.0 \\
0.6 \\
\end{array}$ & $\begin{array}{r}12.6 \\
0.5\end{array}$ & $\begin{array}{l}197.8 \\
618.3\end{array}$ \\
\hline
\end{tabular}

Figure 3 - Population by Age: Projections 2020 to 2060

The shift from a youth-dependent population to an elderly-dependent population has significant implications as discussed above. The combined youth and old-age dependency, however, is even more revealing. Figure 4 below [1, p. 6] reflects this combined dependency on the working age population. From the below figure, two lines in particular are worth noting. In the year 2020, the total dependency ratio, as a measure of the burden on the working age population, is 64. Meaning, in the year 2020, there will be two dependents for every three working age adults. The combined dependency ratio, with the elderly population taking a higher percentage of the total dependency ratio, increases steadily through 2060, the last of the current estimated years. This dependency is, again, a reflection of a slower growing population, a declining fertility rate and a generally aging population. 

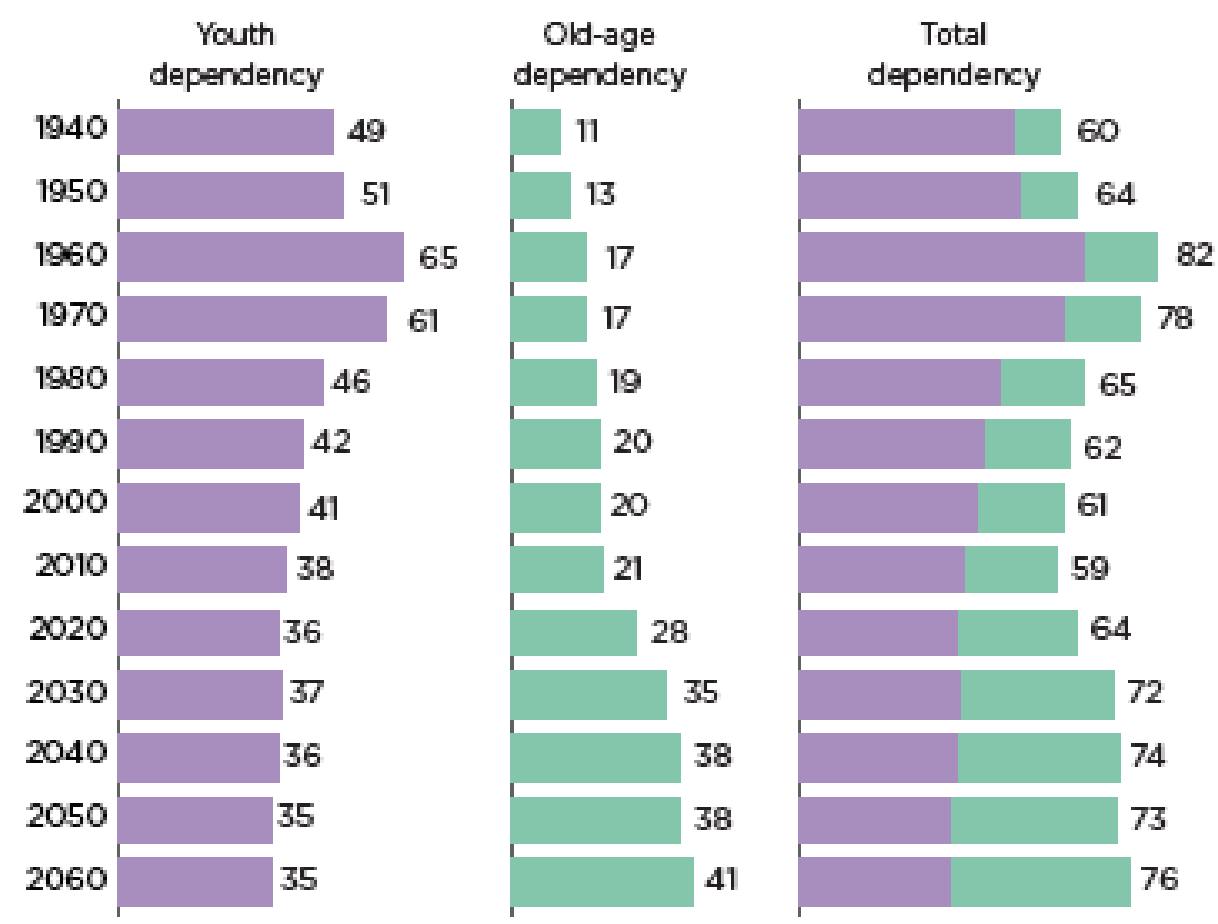

Note: Dependency ratlos are a measure of potentlal burden on the working-age population. Youth dependency ratlo $=($ population under 18 $/$ population aged is to 64) 100 .

ord age dependency ratio $=(\text { population aged } 65 \text { and older } / \text { population aged } 18 \text { to } 64)^{*} 100$. Source: U.S. Census Bureau, 2017 National Population Projections, 1940-2012 Population Estimates.

Figure 4 - Youth and Old-Age Dependency Ratios

\section{Growing Racial and Ethnic Diversities}

The population in general is ageing and growing more slowly. This is especially true for nonHispanic Whites. The fastest growing populations are two or more races (+197\%), Asian (+101\%) and Hispanics (+93\%). Figure 5 [1, p. 7] depicts the percent change from 2016 to 2060. The nonHispanic White population is, again, the only population expected to decline, reflecting a drop of over 19 million people for a percent change rate of $-9.6 \%$. This decline in population reflects the general aging of the population, coupled with the declining fertility rates of this cohort.

While the non-Hispanic White population remains the single largest cohort group, by 2045 they will no longer be the majority of the population of the U.S. 


\begin{tabular}{|c|c|c|c|c|c|c|c|c|}
\hline \multirow{3}{*}{ Characteristics } & \multicolumn{6}{|c|}{ Population } & \multirow{2}{*}{\multicolumn{2}{|c|}{$\begin{array}{l}\text { Change from } \\
2016 \text { to } 2060\end{array}$}} \\
\hline & \multicolumn{2}{|c|}{2016} & \multicolumn{2}{|c|}{2030} & \multicolumn{2}{|c|}{2060} & & \\
\hline & Number & Percent & Number & Percent & Number & Percent & Number & Percent \\
\hline $\begin{array}{l}\text { Total population .................. } \\
\text { One race }\end{array}$ & 323,128 & 100.0 & 354,840 & 100.0 & 403,697 & 100.0 & 80,569 & 24.9 \\
\hline White $\ldots \ldots \ldots \ldots \ldots \ldots \ldots \ldots \ldots$ & 248,503 & 76.9 & 263,302 & 74.2 & 274,576 & 68.0 & 26,073 & 10.5 \\
\hline Non-Hispanic White. ....... . & 197,970 & 61.3 & 197,888 & 55.8 & 178,884 & 44.3 & $-19,086$ & -9.6 \\
\hline Black or African American . ............. & 43,001 & 13.3 & 48,934 & 13.8 & 60,471 & 15.0 & 17,470 & 40.6 \\
\hline American Indian and Alaska Native...... & 4,055 & 1.3 & 4,657 & 1.3 & 5,567 & 1.4 & 1,512 & 37.3 \\
\hline $\begin{array}{l}\text { Asian. ............................. } \\
\text { Native Hawailian and Other Pacific }\end{array}$ & 18,319 & 5.7 & 24,382 & 6.9 & 36,778 & 9.1 & 18,459 & 100.8 \\
\hline Islander........................ & 771 & 0.2 & 912 & 0.3 & 1,124 & 0.3 & 353 & 45.8 \\
\hline Two or More Races . . . . . . . . . . . . . . . . & 8,480 & 2.6 & 12,652 & 3.6 & 25,181 & 6.2 & 16,701 & 196.9 \\
\hline Hispanic. . . . . . . . . . . . . . . . . . . . & 57,470 & 17.8 & 74,751 & 21.1 & 111,022 & 27.5 & 53,552 & 93.2 \\
\hline
\end{tabular}

Figure 5 - Population by Race and Ethnicity

\section{Youth Minority Majority Change in 2020}

The youth of the U.S. are the bench strength of any country's population. They backfill the aging population and are the primary cohort to sustaining age related social programs, the strength of the working class and a country's capacity to innovate. It is, therefore, imperative this population is sufficiently educated and capable of sustaining an on-going enterprise, or in this case, a country.

By the year 2020, less than one half of the children under 18 years of age will be non-Hispanic White. Meaning, a majority of the youth population will be what has been historically known as a minority population; this cross-over has been coined as either the new minority majority, or alternatively, the new majority minority (when referring to the non-Hispanic White population).

Figure 6 below [1, p. 8] depicts this changing demographic. In the year 2020, the non-Hispanic White population will represent 49.8 percent of the total youth cohort. The combined minority populations will exceed the non-Hispanic White population for the first time in U.S. history. From figure 6, by 2060, roughly two in three youth will be non-Hispanic White. This trend is not expected to reverse as significantly greater growth of the combined minority populations outpaces that of the non-Hispanic White cohort. 


\begin{tabular}{|c|c|c|c|c|}
\hline Characteristic & 2016 & 2020 & 2030 & 2060 \\
\hline $\begin{array}{l}\text { Total children under } 18 \\
\quad \text { (in thousands) } \ldots \ldots \ldots \ldots \ldots \ldots\end{array}$ & \multirow[t]{2}{*}{73,642} & \multirow[t]{2}{*}{73,882} & \multirow[t]{2}{*}{75,391} & \multirow[t]{2}{*}{79,788} \\
\hline One race $\ldots \ldots \ldots \ldots \ldots \ldots \ldots$ & & & & \\
\hline White $\ldots \ldots \ldots \ldots \ldots \ldots \ldots \ldots$ & 72.5 & 71.7 & 69.4 & 62.9 \\
\hline Non-Hispanic White ........... & 51.1 & $\Rightarrow 49.8$ & 46.9 & 36.5 \\
\hline Black or African American. . . . . . . . . . & 15.1 & 15.2 & 15.5 & 16.0 \\
\hline American Indian and Alaska Native...... . . & 1.6 & 1.6 & 1.5 & 1.4 \\
\hline $\begin{array}{l}\text { Asian. .............................. } \\
\text { Native Hawaiian and Pacific }\end{array}$ & 5.2 & 5.5 & 6.3 & 8.1 \\
\hline Islander............... . & 0.3 & 0.3 & 0.3 & 0.3 \\
\hline Two or More Races . . . . . . . . . . . . . . . . & 5.3 & 5.8 & 7.1 & 11.3 \\
\hline Hispanic . . . . . . . . . . . . . . . . . . . & 24.9 & 25.5 & 26.5 & 32.0 \\
\hline
\end{tabular}

Note: The official population estimates for the United States are shown for 2016; the projections use the vintage 2016 population estimate for July 1, 2016, as the base population for projecting from 2017 to 2060 . Percentages will not add to 100 because Hispanics may be any race.

Source: U.S. Census Bureau, 2017 National Population Projections.

\section{By 2020, fewer than half of the children will}

be non-Hispanic White

Figure 6 - The 2020 Cross-Over of the New Minority Majority

\section{International Migration}

By 2028, the share of the U.S. population that is considered foreign-born is projected to be higher than any time since 1850 . Figure 8 [1, p. 9] depicts $15.2 \%$ of the entire U.S. population as being foreign-born, exceeding the previous high of 14.8\%; the actual cross-over occurs in 2028. The overall share of the U.S. population that is foreign-born is expected to continue to increase; not because of a growing international migration, but because of a shrinking overall natural-born aging population.

As depicted in figure 8 [1, p. 11], by 2030, net international migration will be the single largest driver of U.S. population growth. In 2030, the net natural-born increase to the population that being the increase due to natural born U.S. citizens, will be roughly 1 million, while at the same time, in 2030, the net international immigration increase in population will be roughly 1.1 million. Through 2060, net international migration population increase will remain stable at 1.1 million, while the natural-born net population increase will continue to decline. This overall population increase reflects an increasing population at a decreasing rate of growth. 


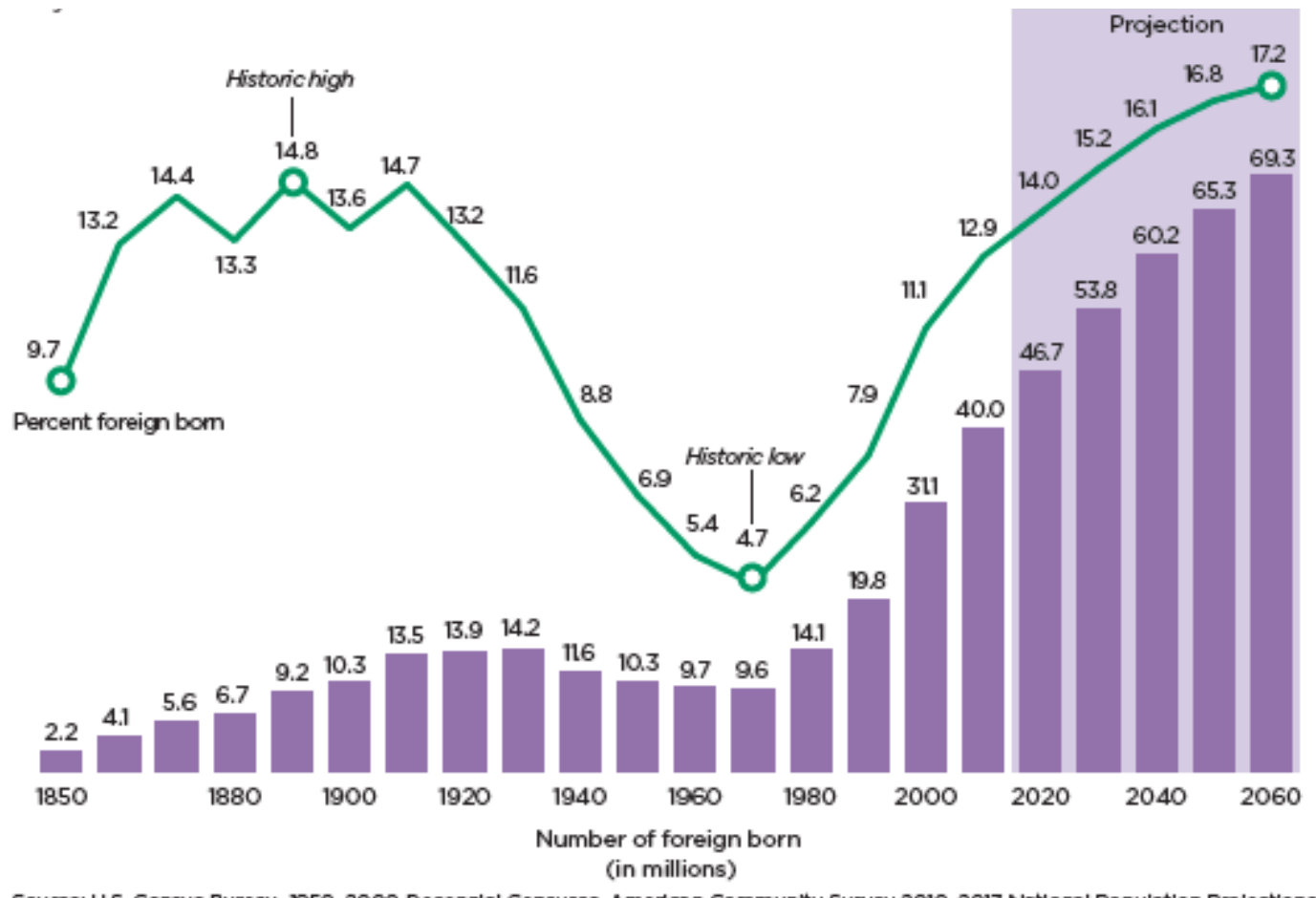

Source: U.S. Census Bureau, 1850-2000 Decenrial Censuses, American Community Survey 2010, 2017 National Population Projections for 2020-2060.

Figure 7 - Foreign-Born as a Percent of Total U.S. Population

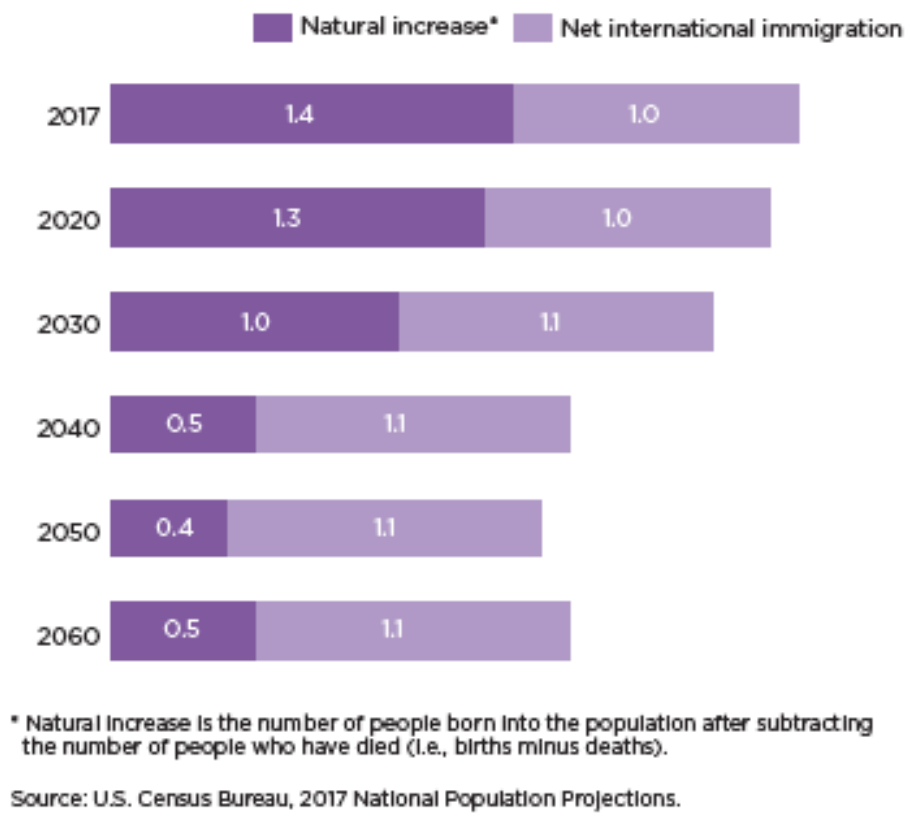

Figure 8 - Total U.S. Increase by Natural, versus International Populations 


\section{College Enrollment Impact [4]}

In the Distance Education Learning Report, Allen and Seaman [3] report higher education enrollments, overall, for academic years spanning 2012-2015, are down across public and private for-profit institutions, while enrollments are slightly higher in private non-profit institutions. Figure 9 below depicts this relationship.

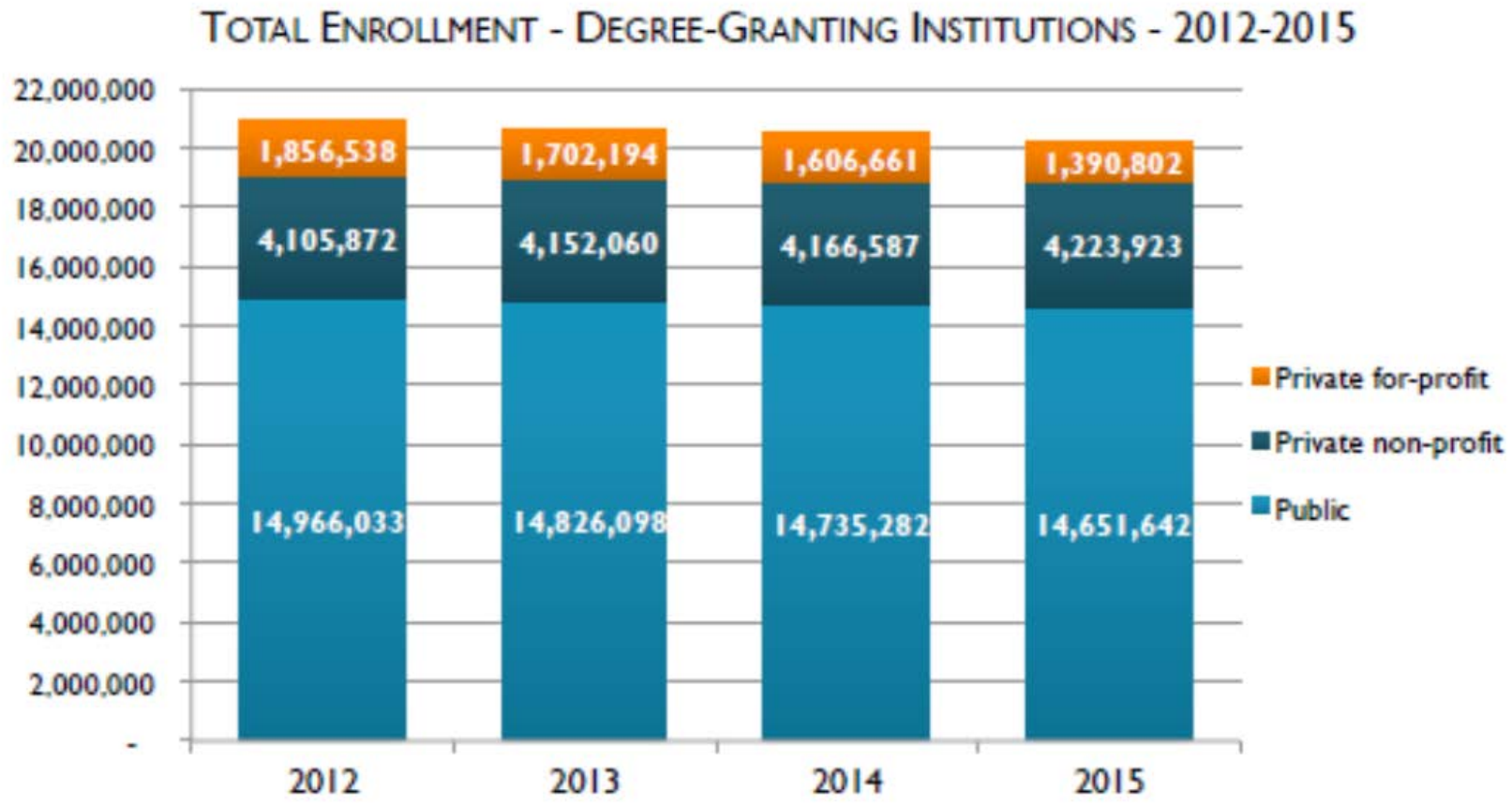

Figure 9 - Enrollments by Type of Institution

The Allen and Seaman data reflects nearly a one million student decrease of $-931,317$ in students studying on campus.

Figure 10 [3] below depicts both the percent change from 2012 - 2015 as well as the equivalent student population. Worth noting is that public universities maintain the predominance of total student enrollments, both as a headcount and as a percentage. 
NUMBER OF STUDENTS STUDYING ON CAMPUS - 2012-2015

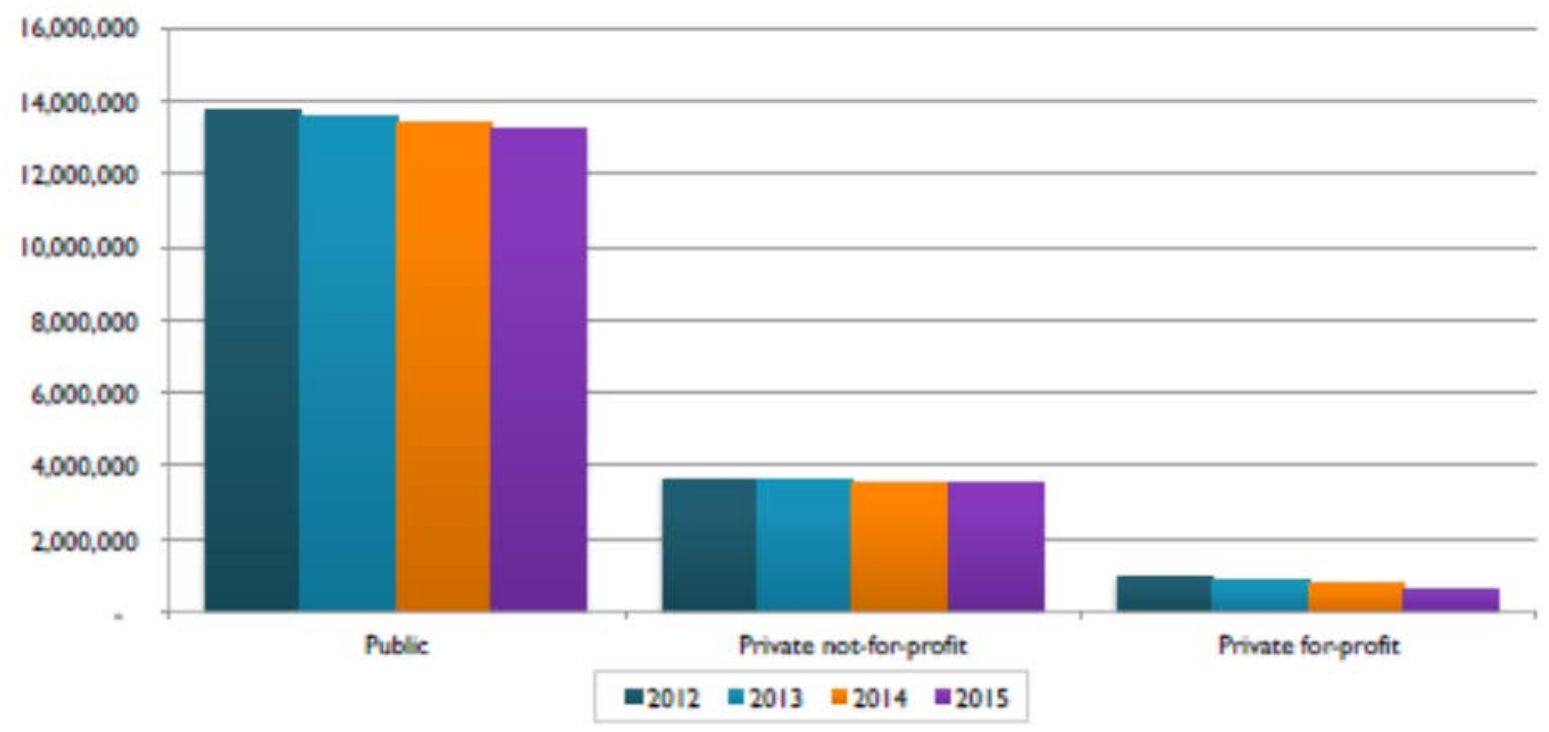

Change in Number of On Campus Students - 2012 to 2015

\begin{tabular}{|lcr|}
\hline & Change 2012 to & Percent Change \\
& 2015 & 2012 to 2015 \\
\hline Public & $(539.271)$ & $-3.93 \%$ \\
\hline Private non-profit & $(100.863)$ & $-2.78 \%$ \\
\hline Private for-profit & $(291.183)$ & $-31.36 \%$ \\
\hline Total & $(931.317)$ & $-5.09 \%$ \\
\hline
\end{tabular}

Figure 10 - Number and Percent of Student Decline from 2012-2015

Looking at the data presented by the authors, one would be naturally compelled to ask "where did nearly one million students go?”

From figure 11 [3], the students did not migrate to those institutions with a negative percent change from 2012-2015; namely, they did not go to private non-profit 4-year or above, private for-profit 4-year or above, public 2-year, or, private for-profit 2-year. It appears the sole significant increase in enrollment institution type was to private non-profit 2-year institutions.

On reflection, if total loses do not add up to equal total gains, then where did the students go? Further research suggests there are simply not as many students; but why? The simple answer can generally be stated as an aging overall demographic population and declining fertility rates [4]. 


\section{On Campus Students - 2012 to 2015}

\begin{tabular}{|lcc|} 
Sector of institution & $\begin{array}{c}\text { Change 2012 } \\
\text { to 2015 }\end{array}$ & $\begin{array}{c}\text { Percent } \\
\text { Change 2012 } \\
\text { to 2015 }\end{array}$ \\
\hline Public, 4-year or above & 101.445 & $1.3 \%$ \\
\hline Private non-profit, 4-year or above & $(113.063)$ & $-3.1 \%$ \\
\hline Private for-profit, 4-year or above & $(181.680)$ & $-31.4 \%$ \\
\hline Public, 2-year & $(640.716)$ & $-10.4 \%$ \\
\hline Private non-profit, 2-year & 12.200 & $32.2 \%$ \\
\hline Private for-profit, 2-year & $(109.503)$ & $-31.4 \%$ \\
\hline Total & $(931.317)$ & $-5.1 \%$ \\
\hline
\end{tabular}

Figure 11 - Allocation by College/University Type of Missing Students

\section{Demographic Deeper Dive by Location and Cohort}

While it can be stated there is a slower growing and generally aging overall population, not every population demographic graduates high school or enters college at the same cohort rate. To be more specific one must look at each location throughout the United States, the demographic makeup of that location and the probability of members of each cohort going to college. This deeper analysis provides a formula for more accurate predictions of college attendance.

The demand for college [5, pgs. 24-25], therefore, may be calculated as follows:

Demand for College (lt) =

- Probability of attendance (lt)

- Number of children (lt)

Where $(\mathrm{l})$ = location, $(\mathrm{t})$ = birth cohorts by year of expected H.S. graduation

College participation may also be viewed as an overlap between birthrate and social-economic factors; in other words, not every demographic cohort goes to college in equal numbers. For example, high-income children participate in some college at a rate of $73 \%$, while low-income children participate in some college at a rate of $30 \%$.

When overlapping birth-rates with racial/ethnic factors, the data suggests the following.

口 Asian Americans participate in some college at a rate of $84 \%$

a Non-Hispanic Whites participate in some college at a rate of $75 \%$ 
- Non-Hispanic Blacks participate in some college at a rate of $60 \%$

口 Hispanics participate in some college at a rate of $60 \%$

When overlapping birthrates with the level of education of a child's parents, the data suggests children whose parents have a degree at the bachelor's level or more are more likely to attend some college than those children whose parents have not completed their H.S. education.

- Childs participation in some college, when parent(s) have a bachelor's degree or more is $87 \%$.

- Childs participation in some college, when parent(s) did not complete High School is 47\%.

\section{Changes in Higher Education}

In reviewing the literature, it can readily be seen the demographics of the United States are changing $[8,9,10,11]$. As a Nation, the United States has a(an):

๑ Aging population

\ Slower growing population

․ Declining fertility rate

․ Smaller youth population than the aging older population

口 Increasing dependence on international immigrants

As the population changes in demographic structure, the new minority populations will become the majority populations. These newer minority majority populations have historically projected entry into college at a lessor rate than the non-Hispanic White population; this due to numerous economic, parental, admissions and other related and previously reported obstacles.

The impact of this new minority majority is now being felt through declining enrollments in our colleges and universities. To this end, the predominantly proposed solutions currently being discussed in the literature and enacted throughout the many post-secondary institutions of higher education in the United States are highlighted below [12, 13, 14, 15].

- Limiting the number of majors and tying those remaining to the needs of the local economy

$\checkmark$ Reaching out to more populous parts of country

口 More international students

口 Offering classes year round

口 Online education: distance learning programs; hybrid classes; fully online degrees; MOOCs for credit

- Simplifying organizational structures by decreasing layers of management 
- Eliminating redundancies in service organizations such as information technology (IT), human resources (HR), finance, or marketing through centralization, and consolidation.

\Consolidation of colleges and universities (37 merged 2011-2013)

- Increased use of adjuncts; reducing percent of tenured faculty

u Programmatic review: elimination of small, underutilized programs. (negative ROI)

The proposed changes to higher education are no longer being reacted to in anticipation of upcoming seismic shifts, but instead in recognition of current realities.

\section{The Cultural Implications of Change}

William Frey [7, pgs. 1-2] in Diversity Explosion: How New Radical Demographics are Remaking America expresses:

"...America reached an important milestone in 2011. That occurred when, for the first time in the history of the country, more minority babies than white babies were born in a year. Soon, most children will be racial minorities: Hispanics, blacks, Asians, and other nonwhite races. And, in about three decades, whites will constitute a minority of all Americans... Certainly in the past, the spector of a "minority white" nation instilled fear among some Americans, and to some extent it continues to do so today - fear of change, fear of losing privileged status, or fear of unwanted groups in their communities..."

Cognitive psychological qualitative research founded in the nurture side of the discussion, begins with a suggestion we are born with two basic characteristics; the need to survive and the need to reproduce [16, pg. 23]. From these two basic instincts, psychologists and cognitive psychologists in particular, suggest we have both an unconscious mind and conscious mind. The unconscious mind, sometimes referred to as our gut feeling, steers us from unsafe situations (survival instinct). The conscious mind, on the other hand, allows us to think through or rationalize the situation, perhaps creating a more informed decision. But, our gut feeling, that emanating from our unconscious mind, is always on, and providing that survival instinct.

This concept of unconscious, intuitive or gut instinct, is argued to be premised in nurture-based activities from birth. The basis for this perspective is solidly founded in one study after the next and the premise for hundreds, if not thousands of articles and books. This animal and human ability to sense insecure initiatives, activities or people is developed out of experience and environmentally created scenarios. The literature suggests, “...there are basic evolved motivations and tendencies, operating exclusively automatically up to age four, when we begin developing conscious intentional control over our minds and bodies... [16, pg. 33]. Our primary, ultimate, deepest evolved motivation for survival and physical safety is at the root of our attitudes and beliefs [16, pg. 43]" 
Feeling safe, or avoiding threats, can be extrapolated to our sense of others. Human beings, dating back to our cave man histories, were the most dangerous creatures around and the greatest threat to our survival. Bargh states [16, pg. 67]

“...these are cues about whether people are similar to us or not. Do they look and sound the same as those around us, such as our parents, siblings and close neighbors? There has been a tremendous amount of research on this in-group versus out-group distinction, and their consequences, in my own field of social psychology over the last fifty years. This research is showing that we are tuned into in-group/out-group distinctions starting at a very young age, indicating it is an innate tendency to do so...baby animals in general have an evolved general predisposition to stay close to those who are similar to them. They don't go off and play on the farmland or forest with other baby animals; instead they stay close to their own kind, the animals who are most like them who will be the ones who take care of them, give them food, provide warmth and shelter, and, most important, don't try to eat them... human beings behave more or less the same way...infants only three months old, given the choice of looking at faces of people who are the same racial-ethnic group as theirs (Caucasian) or the faces of a different racial-ethnic group (African, Middle Eastern, Asian), preferred to look at members of their own group."

In the book The Blind Spot: Hidden Biases of Good People [17], the authors discuss a phenomenon of the human eye, known as a blind spot. A blind spot, scotoma, is an obscurity of the visual field. A particular blind spot known as the physiological blind spot, "blind point", or punctum caecum in medical literature, is the place in the visual field that corresponds to the lack of lightdetecting photoreceptor cells on the optic disc of the retina where the optic nerve passes through the optic disc [18]. Because there are no cells to detect light on the optic disc, the corresponding part of the field of vision is invisible. Some process in our brains interpolates the blind spot based on surrounding detail and information from the other eye, so we do not normally perceive the blind spot.

In figure 12 below, if you close your right eye and look with your left eye at the circle on the left, then, slowly bring the image closer to your face, continuing to look at the left circle with your left eye, eventually the circle disappears and what remains in its place are the filled in lines of the graph, as though the circle never existed. In this instance, the brain recognizes its blind spot and determines what should be in the circles place should likely be what forms the predominate background of the whole image, namely, the checker board pattern. Our mind, has helped us by removing any manifestation of our eye's blind spot. In much the same way, our unconscious mind fills in the blanks that instinctively protect us from harm. 


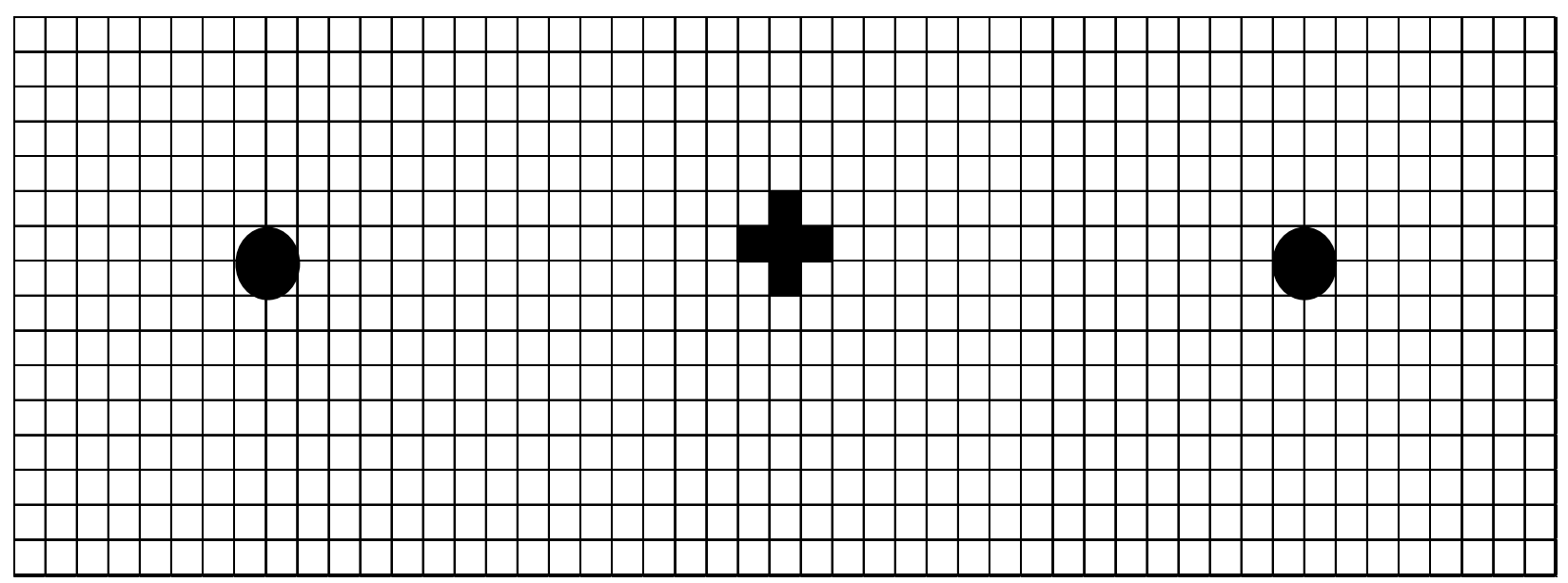

Figure 12 - Human Eye Blind Spot Test

Our motivation for survival and physical safety is at the root of our attitudes and beliefs.

- Are people similar to us or not?

In-group or the out-group?

a Who should we like? Trust?

Who threatens our ethnocentric way of life?

The basic question becomes how do our innate beliefs influence our behaviors?

In the book Our Search for Belonging: How Our Need to Connect is Tearing Us Apart, the authors provide the following [19, pg. 116].

"Once I saw this guy on a bridge about to jump. I said, "Don't do it!" He said, "Nobody loves me." I said, "God loves you. Do you believe in God?" He said, "Yes." I said, “Are you a Christian or a Jew?” He said, “A Christian.” I said, “Me, too!

Protestant or Catholic?” He said, “Protestant.” I said, “Me, too!

What franchise?” He said, "Baptist.” I said, “Me, too!

Northern Baptist or Southern Baptist?” He said “Northern Baptist.” I said, “Me, too! Northern Conservative Baptist or Northern Liberal Baptist?" He said, "Northern Conservative Baptist.” I said, “Me, too!

Northern Conservative Baptist Great Lakes Region, or Northern Conservative Baptist Eastern Region?” He said, "Northern Conservative Baptist Great Lakes Region.” I said, "Me, too! 
Northern Conservative Baptist Great Lakes Region Council of 1879, or Northern Conservative Baptist Great Lakes Region Council of 1912?" He said, "Northern Conservative Baptist Great Lakes Region Council of 1912."

I said, "Die, heretic!” And I pushed him over."

- Emo Philips

How far do we have to search to find something we do not like about another person, race, ethnicity, or the like? What human emotions enter into this equation; anger, jealousy, envy, fear? With the tectonic changes to the demographics of the U.S., what will our citizens find as a reason to not like another? Certainly, with the changes to age, race and ethnicity, there will be sufficient reason to dislike, if society looks to do so.

Scientific historical accounts reflect Homo sapiens, essentially our human evolutionary ancestry, has only existed for a meager 300,000 years in the 4.6 billion years since the origin of the Earth. During this short stint in history, we have experienced an unending series of conflicts. History is proliferated with these many human recorded conflicts; conflicts premised on differences in religion, ethnicity, race, gender, geography and so many more. Our very limited circumference of trust is illustrated even here in our great United States, through a myopic lens and ethnocentric minds-eye. Who should we like? Who should we trust? Who should we not like and/or trust? In the end, who is the next person or group that individually or collectively threatens our survival?

Bias is an unconscious behavior we do not even know we are employing. There are hundreds of studies backing this claim. Three in particular, replicated numerous times, that demonstrate this point follow:

- People in supermarkets buy more French wine when French music is playing

- They buy more German wine when German music is playing

a Tenure screens - More interviews offered male names than female names;

- Regardless of qualifications

- Scientists pay lab techs less if they are women

- Based on their name without seeing them

In the book That's What She Said [20], the author suggests our unconscious mind is required, in order to synchronize and coordinate the billions of pieces of information per second we receive.

“....all of us are bombarded by information, an estimated 11 billion bits of it per second. But we can process just 40 bits per second. So our brains take shortcuts...for our early ancestors, this was literally a lifesaver. 
If a caveman walked out of his cave and saw an animal, he couldn't take the time to consciously process that it had fur, so it wasn't a human; and strong legs, so it must run fast; and sharp teeth, so it must be a carnivore; and...oh, wait, it must be a tiger. By the time he consciously assessed all that, he'd be lunch"

In reexamining our unconscious mind, what suggestions might exist to fix compensating for our blind spots? Bargh [16, pg. 57] provides eight rules for when, or when not, to trust your gut (unconscious mind).

Rule \#1 - supplement your unconscious gut feeling with a minimal level of conscious reflection.

Rule \#2 - when you do not have the time to consciously reflect on the situation, do not take big chances for small gains.

Rule \#3 - when you do not have time to adequately reflect through your conscious mind, or do not have the data in hand to make an informed decision, then take your gut feelings seriously; i.e., not casually.

Rule \#4 - when you trust your gut (unconscious mind), be careful to recognize what you are asking for. Your goals and objectives may taint your mind's eye.

Rule \#5 - when our initial gut reaction to a person of a different race or ethnic group is negative, we should recognize it and stifle it.

Rule \#6 - we should not trust our appraisals of others based on their faces alone, or on photographs, before we have had an interaction with them.

Rule \#7 - you can trust your gut about other people, but only after you have seen them in action.

Rule \#8 - it is perfectly fine for an attraction to be one part of a romantic equation, but not so fine to let it be the only, or even the main, thing.

\section{Concluding thoughts}

The unconscious mind has been formed from birth by our surroundings; people, places, comforts and securities. These same familiarities bring with them a very natural desire to perpetuate the same; the same friendly people, cultural expressions, ethnic, racial and gender comforts. This sameness, has led to common themes - bias, prejudice and discrimination against those who are different; those who do not fit the mold of our secure and comfortable world; those who threaten our status quo, our survival of sameness.

While these many qualitative unconscious behaviors have been proven time and again, there are potential topic areas, once considered, that may mitigate the impact of this desire for sameness. An awareness of the topics of this paper, as listed below, may help to heighten our awareness to what we may unconsciously be considering in our decision making processes. 
a A fundamental understanding of human instincts.

- An understanding of the definitions and manifestations of coercion, groupthink, bias and discrimination.

- The synergy and value add of the business case for growth through inclusion.

- A process approach to improved decision making.

- A better understanding of ourselves through the domains of emotional intelligence.

While this paper focused on those behavioral characteristics attendant to the flaws in the decision making process, it should be noted in closing, that there are attempts to improve these deficiencies. Many universities are working to heighten awareness to the unconscious behaviors contributing to the discussion topics of this paper. These same universities, and others, have taken positive steps to heighten awareness to diversity and inclusivity through our search and screen committees, and, our promotion and tenure practices. While the data reflects a past and current discrepancy in the decision making process and ranks of the academy, there are those colleges and universities that have given diversity extra consideration, and in fairness, this should be noted.

In the final analysis [21, pg. 252], we are nearly identical from a biological perspective. As humans, we have one human genome, made up of approximately 21,000 genes, with roughly 100 trillion cells, where each cell contains 23 pairs of chromosomes. Stated another way, for every cell with a nucleus, there are 23 pairs of chromosomes, where the pairs contain the 3.2 billion base pairs of "T," "A," "C," and "G." Combinations of these base pairs form our roughly 21,000 genes. Genes (DNA) transmit information to our cells through RNA to tell them which proteins to create. Proteins, then, are what keep us functioning. Understanding the makeup of each gene is an enormous first step to disease control.

Interestingly, however, we actually share 51 percent of our genes with yeast, the stuff used to make bread rise. We share 98 percent of our genes with monkeys. And, most impressively, we share 99.9 percent of our entire genome with other human beings. That means the only thing that separates brown hair from blond hair, five-foot-nine-inch stature from six-foot-tall stature, and blue eyes from hazel eyes are 0.1 percent of the entire human genome. That's one-tenth of one percent that differentiates each of us on this planet. In other words, as a species, we are more alike than different - at least from a human genome perspective. The thought of that is so profound that it reverberates and should simultaneously magnify the historical significance of our biases and prejudices, or more precisely, perhaps the insignificance they should have been and why they should not have existed at all. 


\section{References}

[1] Vespa, J., Armstrong, D., and Medina, L. (2018). Demographic Turning Points for the United States: Population Projections for 2020 to 2060. Current population Reports, P25-1144, U.S. Census Bureau, Washington, DC.

[2] U.S. Census Bureau (2018). Older People Projected to Outnumber Children for First Time in U.S. History. United States Census Bureau, March 13, 2018. Release Number CB18-41.

[3] Allen, I., Seaman, J (2017). Digital Learning Compass: Distance Education Enrollment Report 2017. Babson Survey Research Group.

[4] Springer, M. L., \& Schuver, M. T. (2018). Dwindling Graduate Student Enrollments in Distance-Based Programs: A Research-Based Exploration with Findings and Underlying Premise. ASEE 2018 Annual Conference Proceedings. Salt Lake City, UT.

[5] Grawe, N, (2018). Demographics and the Demand for Higher Education. Baltimore, MD., Johns Hopkins University Press.

[6] Bransberger, P., Michealu, D. (2016). Knocking at the College Door - Projections of High School Graduates. Western Interstate Commission for Higher Education, Updated July 2017.

[7] Frey, W. (2018). Diversity Explosion: How New Racial Demographics Are Remaking America. Washington, D.C., The Brookings Institution.

[8] Moody's US Higher Education Outlook Negative in 2013. Industry Outlook, January 16, 2013. Downloaded from http://www.marquette.edu/budget/documents/USHigherEducationOutlookNegativein2013.pdf (2013).

[9] Marcus, J. Like Private Businesses, Universities Consolidate to Cut Costs. The Hechinger Report. Downloaded from http://nation.time.com/2013/07/19/cash-strapped-universities-turn-to-corporate-styleconsolidation/?xid=newsletter-daily. (2013).

[10] Selingo, J., Carey, K., Pennington, H., Fishman, R. \& Palmer, I. The Next Generation University. New America Foundation, May 2013. Downloaded from the internet on July 19, 2013. http://higheredwatch.newamerica.net/blogposts/2013/the_next_generation_university-84378 (2013).

[11] Kiley, K. Where Universities Can Be Cut. Inside Higher Education Online. Downloaded from http://www.insidehighered.com/news/2011/09/16/unc_berkeley_cornell_experience_show_where_administ rative_cuts_can_be_made (2011).

[12] Wessel, D. Four Ideas to Fix Higher Education. The Wall Street Journal Online. Downloaded from http://online.wsj.com/article/SB10001424127887323971204578626123435046376.html (2013).

[13] National Academy of Sciences. Research Universities and the Future of America: Ten Breakthrough Actions Vital to our Nation's Prosperity and Security. Washington, D.C.: National Academies Press (2012).

[14] Carlson, S. (2018). Sustaining the College Business Model. The Chronicle of Higher Education.

[15] Student Loan Hero. (2018). A Look at the Shocking Student Loan Debt Statistics for 2018. Student Loan Hero. Downloaded from https://studentloanhero.com/student-loan-debt-statistics/.

[16] Bargh, J. (2017). Before You Know It. New York, N.Y., Simon \& Schuster.

[17] Banaji, M. \& Greenwald, A. (2016). Blind Spot: Hidden Biases of Good People. New York, N.Y., Bantam.

[18] Wikipedia, downloaded from https://en.wikipedia.org/wiki/Blind_spot_(vision).

[19] Ross, H., Tartaglione, J. \& Cole, J. (2018) Our Search for Belonging: How Our Need to Connect is Tearing Us Apart. New York, N.Y., Berrett-Koehler Publishers.

[20] Lipman, J. (2018). That’s What She Said. New York, N.Y., HaperCollins Publishers.

[21] Springer, M. L. (2019). Project and program management: A competency-based approach. 4th ed. West Lafayette, IN: Purdue University Press. 